\title{
Evaluation of Antispasmodic Effect of Arcapillin on Smooth Muscles of Rats
}

\author{
Lubna F. Abu-Niaaj ${ }^{1, *}$, Ibrahim Katampe ${ }^{1}$, Shtaywy S. Abdalla ${ }^{2}$
}

Lubna F. Abu-Niaaj ${ }^{1, *}$, Ibrahim Katampe ${ }^{1}$, Shtaywy S. Abdalla $^{2}$

'Department of Agricultural and Life Sciences, Central State University, Wilberforce, $\mathrm{OH}$ 45384, USA

${ }^{2}$ Department of Biological Sciences, University of Jordan, Amman, JORDAN.

\section{Correspondence}

\section{Lubna F. Abu-Niaaj}

Assistant Professor of Biology, Department of Agricultural and Life Sciences, Central State University, 1400 Brush Row Road, Wilberforce, $\mathrm{OH}$ 45384, USA

Phone no: + (01) 9373766360

E-mail: Labu-niaaj@centralstate.edu History

- Submission Date: 24-11-2018;

- Review completed: 06-04-2019;

- Accepted Date: 19-04-2019.

\section{DOI : 10.5530/pj.2019.11.113}

Article Available online

http://www.phcogj.com/v11/i4

\section{Copyright}

(C) 2019 Phcogi.Com. This is an openaccess article distributed under the terms of the Creative Commons Attribution 4.0 International license.

\begin{abstract}
Background: Arcapillin, 2',4',5-trihydroxy-5',6,7-trimethoxyflavone, is a flavone aglycone isolated from several Artemisia species, though, it was first identified from A. capillaris. The Artemisia species are used in folk medicine as a remedy for gastrointestinal and liver illnesses, hypertension, fever and inflammation. Studies indicated a potential role of arcapillin to relieve symptoms of liver disorders; however, there is no report yet in the literature of its effect on smooth muscles. Objective: Our study aims to evaluate the effect of arcapillin, isolated from A. monosperma, on the contractile activity of rat smooth muscles. Materials and Methods: Increased concentrations of arcapillin were tested on isolated rat ileum, pulmonary artery, trachea, and urinary bladder. The muscle contraction was recorded upon addition of arcapillin in eight cumulative concentrations of half log units in the range of $\left[10^{-7} \mathrm{M}-3 \times 10^{-4} \mathrm{M}\right]$. Depending on the organ-containing muscles, the preparations were treated with arcapillin either at basal tonus or after pre-stimulated via a contractile agent; $10^{-3} \mathrm{M} \mathrm{O}$-acetylcholine on ileum and $10^{-5} \mathrm{M}$ L-phenylephrine on pulmonary artery rings. Control tissues were treated with sodium hydroxide in an equivalent concentration to that used to dissolve the flavone. Results: Arcapillin caused a dose-dependent relaxation on ileum preparation and pulmonary artery. The inhibition of the contractile activity of ileum was reversible within 60 seconds after washing off the flavone. The urinary bladder showed a slight increase in contraction at the highest concentrations starting at $\left[10^{-4} \mathrm{M}\right]$ of arcapillin. There was no observed effect on the contraction of tracheal smooth muscles by all tested concentrations of arcapillin. Conclusion: The antispasmodic activity of arcapillin may contribute to the pharmaceutical importance of $A$. monosperma in particularly to treat gastrointestinal disorders.
\end{abstract}

Key words: Arcapillin, Artemisia monosperma, Flavone, Antispasmodic, Smooth Muscles.

\section{INTRODUCTION}

Artemisia monosperma (Delile) is among the Artemisia species used in traditional medicine mainly for the treatment of gastrointestinal and liver disorders, ${ }^{1}$ diabetes, ${ }^{2}$ inflammation, and fever. ${ }^{3}$ It is also known to relieve menstruation pain and to induce labor. ${ }^{4-7}$ An air-dried powdered drug of the plant exhibited antispasmodic activity in the treatment of colic or in conditions associated with arterial hypertension. ${ }^{1}$ Different extracts of $A$. monosperma exhibited a wide spectrum of biological actions such as muscle relaxation, ${ }^{6-8}$ antidiabetic, ${ }^{1,8}$ and antimicrobial activities. ${ }^{9-14}$ Bioactive compounds isolated from Artemisia species showed antispasmodic, ${ }^{15,16}$ antihypertensive, ${ }^{17}$ antimicrobial, ${ }^{12,13}$ insect repellents, ${ }^{18-20}$ antitumor and anti-inflammatory activities. ${ }^{21-23}$ Arcapillin was first identified from A. capillaris ${ }^{24}$ and it was reported an antihepatotoxic. ${ }^{25-27}$ There is no study yet to highlight the effects of arcapillin on vertebrate muscles. This study aims to evaluate the effect of arcapillin on the contractile activity of rat smooth muscles.

\section{MATERIALS AND METHODS}

Isolation of Arcapillin

Arcapillin was isolated from the methanol extract of Artemisia monosperma (Delile). A description of the protocol used for the isolation of this flavone and the methodologies for its identification is detailed in Abu-Niaaj and Katampe 2018. ${ }^{28}$

Animals and preparations of smooth muscle tissues

Male and female virgin rats (150-250 g) were used to obtain ileum, trachea, pulmonary artery and urinary bladder. Animals were housed at standard conditions with adequate access to food and water. The research was conducted in accordance with the internationally accepted guidelines for Laboratory Animal Care and Use (NIH publication number 85-23; revised 1985). The selected organs were obtained immediately after euthanizing the animal and were placed in an oxygenated Physiological Salt Solution (PSS) at $37^{\circ} \mathrm{C} \pm 0.5$ to be cleaned gently from surrounding connective tissue. The ileum was flushed twice with PSS to remove contents then cut into $1-2 \mathrm{~cm}$ long pieces. The urinary bladder was cut from the neck region and from the distal end to allow insertion of a polyethylene tube into its lumen. The organ was flushed with aerated PSS and pieces of 3-5 $\mathrm{mm}$ were obtained from the middle region. The trachea and pulmonary artery were cut into $3-5 \mathrm{~mm}$ rings after inserting fine polyethylene tubing into the lumen to avoid injury during surgical manipulation. For each set of experiment, two tissue pieces were used; 
one piece was treated with increasing cumulative concentrations of arcapillin while the other piece was control treated with $\mathrm{NaOH}$ solution as it was used to dissolve arcapillin. Each tissue piece was individually mounted in glass tissue bath filled with warm PSS at $37^{\circ} \mathrm{C}$, continuously aerated with $95 \% \mathrm{O}_{2}: 5 \% \mathrm{CO}_{2}$. The piece of tissue was tied at one end by a thread to a glass hook fixed at the bottom of the tissue bath, while the other end of the tissue was tied by a long thread connected to the transducer connected to the oscillography. Appropriate tensions were applied on tissues; $2.5 \mathrm{~g}$ on ileum and urinary bladder, and a tension of $3.5 \mathrm{~g}$ was applied on the pulmonary artery and tracheal rings. The isometric contraction of muscle preparations was recorded using force transducers (UF1) connected to a Palmer Bioscience (England) oscillography.

\section{Preparation of solutions}

\section{Arcapillin solution}

Arcapillin stock solution was prepared by dissolving the entire quantity $(180 \mathrm{mg})$ isolated from A.monosperma ${ }^{28}$ in $0.1 \mathrm{~N} \mathrm{NaOH}(3 \mathrm{ml})$ and the volume was completed to $10 \mathrm{ml}$ using PSS. The solution was refrigerated in a dark bottle to avoid photooxidation and/or degradation. Working solutions were prepared shortly before use and warmed to $37^{\circ} \mathrm{C}$ in a water bath before added to tissues.

\section{Physiological salt solution (PSS)}

Fresh PSS buffer was prepared prior to the experiment by dissolving salt ingredients in distilled water to obtain $(\mathrm{mM}): \mathrm{NaCl} 118 ; \mathrm{KCl} 4.7$; $\mathrm{CaCl}_{2} 2.5 ; \mathrm{MgCl}_{2}$ 0.5; $\mathrm{NaH}_{2} \mathrm{PO}_{4} 1.0 ; \mathrm{NaHCO}_{3} 25.0$; glucose 11.1. The $\mathrm{pH}$ was adjusted to 7.4 and the buffer was continuously aerated with $95 \% \mathrm{O}_{2}: 5 \% \mathrm{CO}_{2}$. The temperature was maintained at $37^{\circ} \mathrm{C}$ in a water bath before use.

\section{Other solutions}

The stock and working solutions of L-phenylephrine hydrochloride (Tokyo, Kasei, TCI) were prepared using saline. Papaverine hydrochloride solutions were prepared using distilled water. All stock solutions were refrigerated immediately after preparation. Promptly before use, working solutions were prepared and warmed in a water bath to $37^{\circ} \mathrm{C}$.

\section{Protocol for experimentation on tissues}

Tissues were allowed to equilibrate in tissue baths for $60 \mathrm{~min}$ in oxygenated PSS buffer at $37^{\circ} \mathrm{C} \pm 0.5$, except for the urinary bladder which was allowed to equilibrate for $45 \mathrm{~min}$. The buffer was changed every $15 \mathrm{~min}$ to wash out metabolites. After equilibration, pulmonary artery rings were precontracted with $10^{-5} \mathrm{M}$ L-phenylephrine and allowed to equilibrate for $25-30 \mathrm{~min}$ before establishment of the concentration-effect curve of arcapillin. Control tissues were treated with $\mathrm{NaOH}$ using the same concentration used to dissolve arcapillin. The concentration-effect curve for the treated tissue with arcapillin was established by adding eight cumulative concentrations of half log units increase in the range of $\left[10^{-7} \mathrm{M}-3 \times 10^{-4} \mathrm{M}\right]$. After addition of the highest concentration, the ileum and pulmonary artery rings were subjected to $10^{-3} \mathrm{M}$ papaverine to induce maximum relaxation which was expressed as $100 \%$ tissue relaxation. The relaxation induced by arcapillin was then calculated as a percentage in reference to the maximum relaxation caused by papaverine.

\section{Statistical analysis}

Data are presented as mean \pm standard error of the mean (SEM). $t$-test was calculated for paired samples to compare the control samples to those treated with arcapillin and differences were considered significant when $\mathrm{P}<0.05$. The value of the half maximum effective concentration
$\left(\mathrm{EC}_{50}\right)$ of arcapillin on ileum and pulmonary artery were visually fitted from experimental plots as shown in Figure 3.

\section{RESULTS}

\section{Identification of Arcapillin}

Arcapillin, a 2',4',5-trihydroxy-5',6,7-trimethoxyflavone, was identified for the first time from A. monosperma. ${ }^{28}$ It was characterized using TLC, MS, NMR, and UV chemical fingerprinting methods. The ${ }^{1} \mathrm{H}-\mathrm{NMR}$ and MS are shown in Figure 1.<smiles>COc1cc(-c2cc(=O)c3c(O)c(OC)c(OC)cc3o2)c(O)cc1O</smiles>

\section{Physiological effect of Arcapillin on rat smooth muscles}

Arcapillin in the range of $10^{-7} \mathrm{M}-3 \times 10^{-4} \mathrm{M}$ caused a concentrationdependent relaxation of the tone and phasic contraction of the ileal segments. This inhibition was reversible within one minute upon washing the tissue with PSS (Figures $2 \mathrm{~A}$ and $3 \mathrm{~A}$ ). Arcapillin caused a tone relaxation of L-phenylephrine-precontracted pulmonary artery rings in a concentration-dependent manner (Figures $2 \mathrm{~B}$ and $3 \mathrm{~B}$ ). Compared to the maximum relaxation caused by $10^{-3} \mathrm{M}$ papaverine, the induced inhibition induced by highest concentration $\left(10^{-4} \mathrm{M}\right)$ of arcapillin was $65.6 \% \pm 6.4(\mathrm{P}<0.05)$ on ileum, and $70.9 \% \pm 4.9(\mathrm{P}<$ 0.02 ) on pulmonary artery (Table 1 ). The calculated $\mathrm{EC}_{50}$ of arcapillin from the experimental plots in Figure 3 were $(2.8 \pm 0.6) 10^{-5} \mathrm{M}$ on the ileum and $(5.8 \pm 0.6) 10^{-5} \mathrm{M}$ on the pulmonary artery. The urinary bladder showed a slight increase of the phasic contractions at higher concentrations $\left(3 \times 10^{-5}\right.$ to $\left.3 \times 10^{-4} \mathrm{M}\right)$; however, no effect was observed at the low concentrations $\left(10^{-7}\right.$ to $10^{-5} \mathrm{M}$ ) (Figure $2 \mathrm{C}$ ). Arcapillin showed no effect on the contractile tone of the tracheal rings (data not shown).

\section{DISCUSSION}

Flavonoids are bioactive compounds with a wide spectrum of biological activities including their effects on smooth muscles. ${ }^{8,15,16,29,30}$ Artemisia monosperma is a good source of flavonoids and is reputed in folk medicine in the Middle East for the relief of abdominal illness, inflammation and for inducing labor. Several flavonoids isolated from A. monosperma were reported to induce relaxation of different rat smooth muscles. ${ }^{15-16}$ We reported the first-time isolation of arcapillin from A.monosperm. ${ }^{28}$ This study aim was to evaluate the pharmacological effects of this flavone on vertebrate smooth muscle which has not yet reported in the literature. Our data show a disparity of effects on isolated rat smooth muscles of different organs upon being treated with arcapillin. There was a significant inhibition of the contractile activity of ileum and pulmonary artery but a slight increase in the contraction of urinary bladder at a concentration higher than $3 \times 10^{-5} \mathrm{M}$. There was no effect observed on the tone of tracheal muscles. The difference in arcapillin effects on rat smooth muscles might be due to the diverse properties of these muscles in different organs or maybe caused by different mechanisms of action. Flavonoids were reported as blockers for ion channels including those for calcium and potassium..$^{30-33}$ They also act as inhibitors of selective enzymes including cyclic AMP phosphodiesterase. ${ }^{34-36}$ Arcapillin was reported as an inhibitor of $\alpha$-glucosidase, and as a protein tyrosine phosphatase $1 \mathrm{~B} .{ }^{37,38}$ Tyrosine kinase inhibitors reduce the amplitudes of contractions of intact smooth muscle stimulated by muscarinic or 
(a)

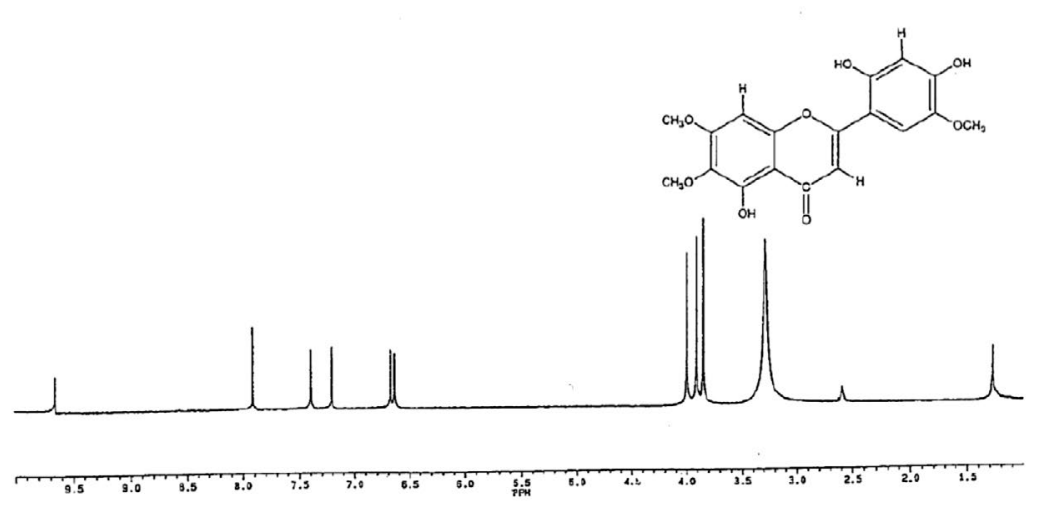

(b)

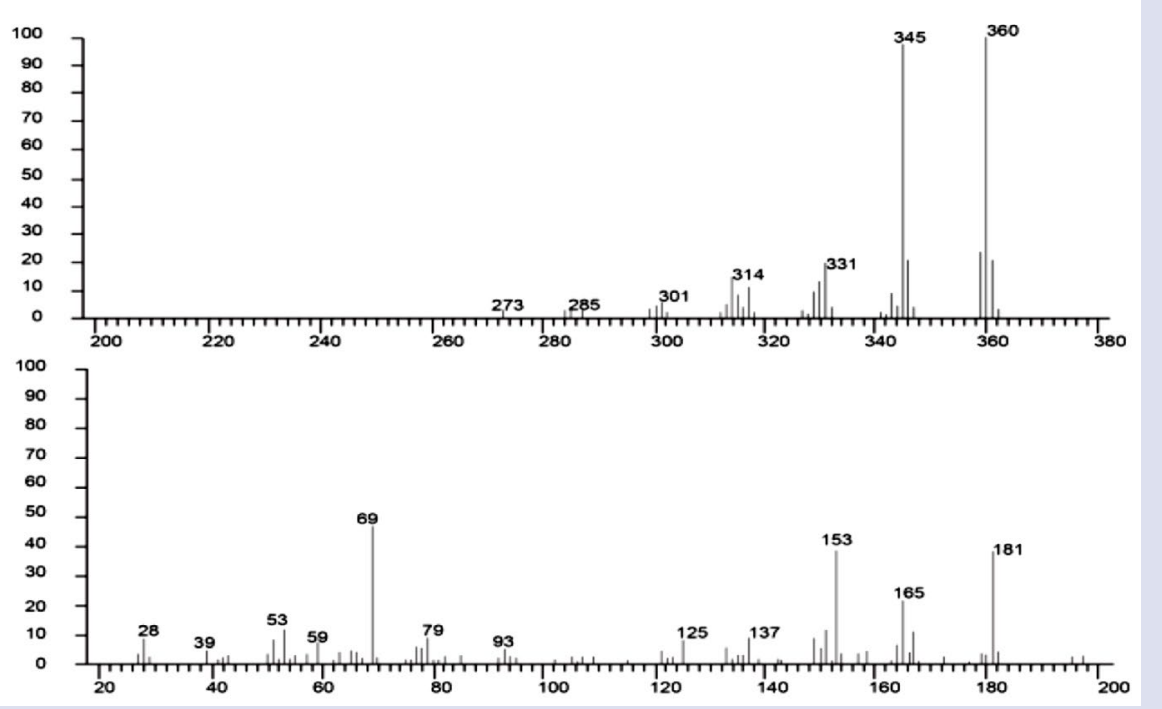

Figure 1: ${ }^{1} \mathrm{H}$-Nuclear magnetic resonance (a) and Mass spectroscopy (b) of Arcapillin.
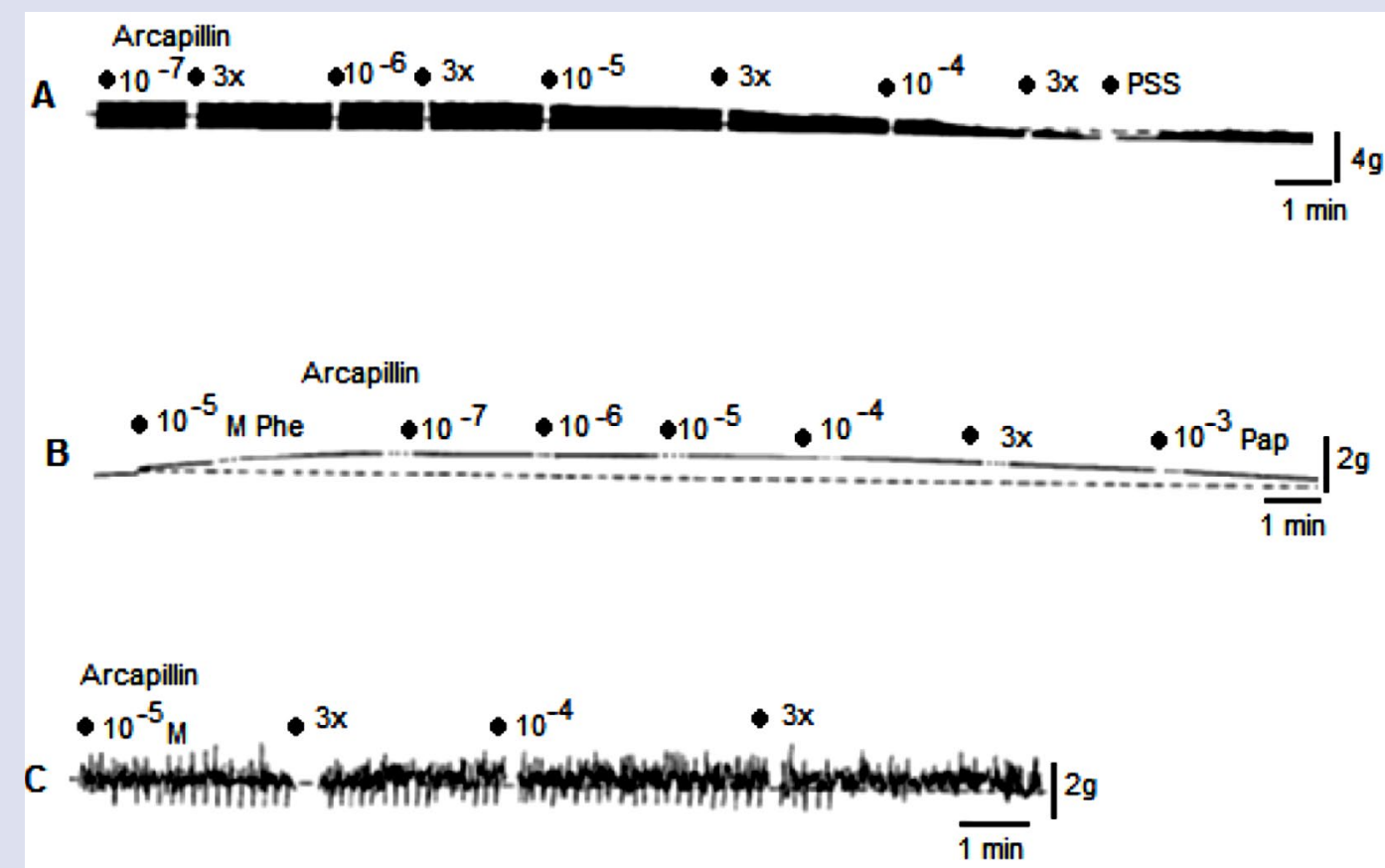

Figure 2: Typical traces showing effects of increasing concentrations of arcapillin on rat isolated tissues: (A) ileum, (B) Pulmonary artery, and (C) urinary bladder. 

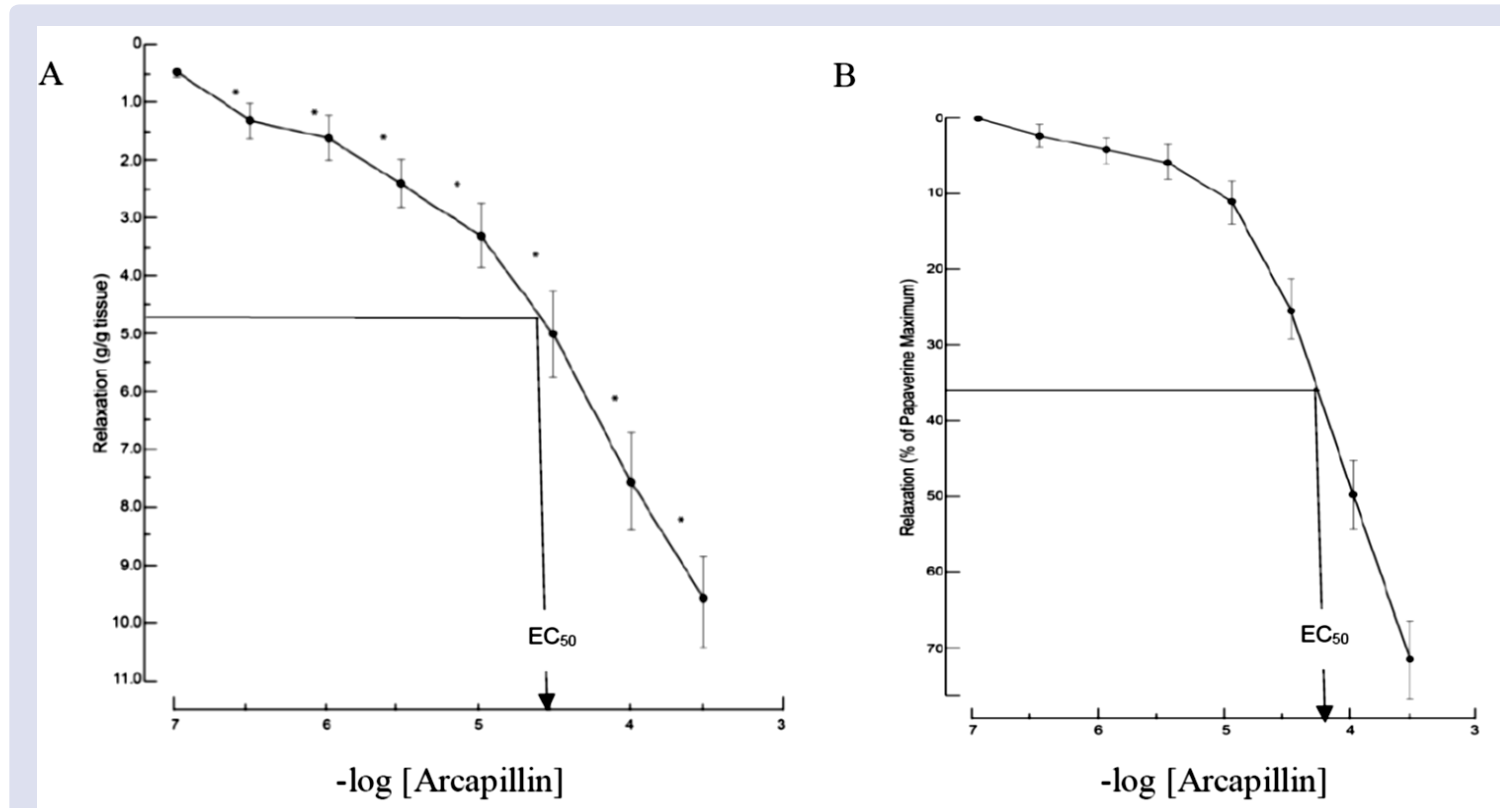

Figure 3: Arcapillin concentration-effect curves (A) ileal muscles (B) pulmonary artery. Vertical bars represent SEM. The EC $C_{50}$ of arcapillin on ileum and pulmonary artery were visually fitted from the experimental plots as shown on the graph.

Table 1: Arcapillin $\mathrm{EC}_{50}$ on rat ileum and pulmonary artery and the \% maximum relaxation induced by arcapillin compared to that $\%$ of papaverine maximuma.

$\begin{array}{cccc}\text { Tissue } & \mathrm{N}^{\mathrm{b}} & \mathrm{EC}_{50}(\mathrm{M}) & \begin{array}{c}\text { \% Max. relaxation induced by Arcapillin compared to } \\ \text { the max. relaxation caused by } 10^{-3} \mathrm{M} \text { Papaverine }\end{array} \\ \begin{array}{c}\text { Ileum } \\ \begin{array}{c}\text { Pulmonary } \\ \text { artery }\end{array}\end{array} & 9 & (2.8 \pm 0.6) 10^{-5} & 65.6 \pm 6.4(\mathrm{P}<0.05) \\ & 9 & (5.8 \pm 0.6) 10^{-5} & 70.9 \pm 4.9(\mathrm{P}<0.02) \\ \end{array}$

${ }^{a}$ Data are presented as mean $\pm \mathrm{SEM} ;{ }^{\mathrm{b}} \mathrm{N}=$ Number of experiments

$\alpha$-adrenergic agonists. ${ }^{39}$ It is possible that the relaxant effect of arcapillin on ileum and pulmonary artery is caused by the decreased cytosolic calcium concentration which subsequently affects calcium availability to the intracellular proteins, or might be due to the activation of potassium channels. ${ }^{30-34}$ It is also possible that the induced relaxation of ileum by arcapillin is due to the inhibition of the phosphodiesterase enzyme causing an elevation in the cellular cAMP; however, the increased contractility of the urinary bladder could be due to affecting the $\alpha$-adrenergic receptors. ${ }^{33,34,39}$ Overall, the antispasmodic activity of arcapillin is moderate compared to other flavones which most likely caused by its structural configuration as a $2^{\prime}, 4,5$-trihydroxy5',6,7-trimethoxyflavone. It is known that the diversity of functional groups of flavonoids contributes to their variable biological activities and potency. ${ }^{40}$ Structural-activity studies show that the number and position of methyl and hydroxyl groups of flavonoids influence the strength of their bioactivity. Studies showed that methylated flavonoids at the 7-position with a free hydroxyl group at the 2 'position are less effective as bioactive compounds. ${ }^{36}$ The absence of a hydroxyl group at position 3 in flavones showed a decreased antioxidant activity ${ }^{38}$. It was shown that the presence of more hydroxyl groups at the $33^{\prime}, 4$, and 7 positions increased effectiveness of flavones in inhibiting the formation of advanced glycation end products. ${ }^{41,42}$ Flavones with more hydroxyl groups at $4^{\prime}, 5^{\prime}, 6^{\prime}, 6$ were reported to induce higher ex vivo relaxant effect on tracheal rat muscle. ${ }^{43}$ Furthermore, studies showed that flavones having free hydroxyl groups in the ortho positions at carbons 5 and 7 of the A- ring were more potent bioactive than those lacking this configuration. ${ }^{44}$ Collectively, the structure of arcapillin may explain its moderate bioactivity in this study. The precise mechanism of action on muscles should be further investigated.

\section{CONCLUSION}

This study demonstrates that arcapillin has a significant spasmolytic activity on the intestinal smooth muscles, which justifies the use of A. monosperma to relieve pain of gastrointestinal disorders. It is most likely that this flavone may be responsible in part of the pharmaceutical importance of Artemisia species which are rich in bioactive flavonoids.

\section{ACKNOWLEDGEMENT}

The authors acknowledge Central State University and the University of Jordan for the provided technical support.

\section{CONFLICTS OF INTEREST}

The authors declared no conflicts of interest.

\section{ABBREVIATIONS}

TLC: Thin Layer Chromatography; MS: Mass Spectroscopy; NMR: Nuclear Magnetic Resonance; UV: Ultraviolet; $\mathrm{NaCl}$ : Sodium Chloride; $\mathrm{KCl}$ : Potassium Chloride; $\mathrm{CaCl}_{2}$ : Calcium Chloride; $\mathrm{MgCl}_{2}$ : Magnesium Chloride; $\mathrm{NaH}_{2} \mathrm{PO}_{4}$ : Sodium Dihydrogen Phosphate; $\mathrm{NaHCO}_{3}$ : Sodium Bicarbonate.

\section{REFERENCES}

1. Bora KS, Sharma A. The genus Artemisia: A comprehensive review. Pharmaceutical Biology. 2011;49(1):101-9.

2. Dabe NE, Kefale AT. Antidiabetic effects of Artemisia species: A systematic review. ANC Sci Life. 2017;36(4):175-81. 
3. Giangaspero A, Ponti C, Pollastro F, Favero GD, Loggia RD, Tubaro A, et al. Topical anti-inflammatory activity of eupatilin, a lipophilic flavonoid from mountain wormwood (Artemisia umbelliformis Lam). J Agric Food Chemistry. 2009:57:7726-30.

4. Mohamed AE, El-Sayed MA, Hegazy ME, Helaly SE, Esmail AM, Mohamed NS. Chemical constituents and biological activities of Artemisia herba-alba. Records of Natural Products. 2010;4(1):1-25.

5. Khan M, Mousa AA, Syamasundar KV, Alkhathlan HZ. Determination of chemical constituents of leaf and stem essential oils of Artemisia monosperma from central Saudi Arabia. Nat Prod Communication. 2012;7(8):1079-82.

6. Hijazi AM, Salhab AS. Effects of Artemisia monosperma ethanolic leaves extract on implantation, mid-term abortion and parturition of pregnant rats. J Ethnopharmacology. 2010;128(2):446-51.

7. Akour A, Kasabri V, Afifi FU, Bulatova N. The use of medicinal herbs in gynecological and pregnancy-related disorders by Jordanian women: A review of folkloric practice vs. evidence-based pharmacology. Pharmaceutical Biology. 2016;54(9):1901-18.

8. Zalabani SM, Tadros SH, El Sayed AM, Daboub AA, Sleem AA. Chemical profile and biological activities of essential oil of aerial parts of Artemisia monosperma Del. growing in Libya. Pharmacognosy J. 2017; 9(4):578-86.

9. Abou-Zeid AM, Altalhi AD, Abd El-Fattah RI. Fungal control of pathogenic fungi isolated from wild plants in Taif Governorate, Saudia Arabia. Roum Arch. Microbiol Immunol. 2007;66(3-4):90-6.

10. Stavri M, Ford $\mathrm{CH}$, Bucar F, Streit $B$, Hall M L, Williamson RT, et al. Bioactive constituents of Artemisia monosperma. Phytochemistry. 2005;66(2):233-9.

11. Sengul M, Ercisli S, Yildiz H, Gungor N, Kavaz A, Cetin B. Antioxidant, antimicrobial activity and total phenolic content within the aerial parts of Artemisia absinthum, Artemisia santonicum and Saponaria officinalis. Iranian $J$ Pharmacological Research. 2011;10(1):49-56.

12. Guetat A, Al-Ghamdi FA, Osman AK. The genus Artemisia L. in the Northern region of Saudi Arabia: Essential oil variability and antibacterial activities. Natural Products Research. 2017;31(5):598-603.

13. Pandey AK, Singh P. The genus Artemisia: a 2012-2017 literature review on chemical composition, antimicrobial, insecticidal, and antioxidant activities of essential oils. Medicines. 2017;4(3):68-82.

14. Shahat AA, Alsaid MS, Ibrahim A, Elsaid M. Polyphenolic content and antioxidant activity of some wild Saudi Arabian Asteraceae plants. Asian Pacific $\mathrm{J}$ of Trop Med. 2014;7(7):545-51.

15. Abu-Niaaj L, Abu-Zarga M, Abdalla S. Isolation and biological effects of eupatilin, a flavone isolated from Artemisia monosperma (Del.) on rat isolated smooth muscles. International J Pharmacog. 1996;34(2):134-40.

16. Abu-Niaaj L, Abu-Zarga M, Sabri S, Abdalla S. Isolation and biological effects of 7-O-methyleriodictiol, a flavanone isolated from Artemisia monosperma, on rat isolated smooth muscles. Planta Med. 1993;59(1):42-5.

17. Ben-Nasr H., Ben Abderrahim MA, Salama M, Ksouda K, Zeghal K-M. Potential phytotherapy use of Artemisia plants: Insight for anti-hypertension. Journal of Applied Pharmaceutical Science. 2013;3(05):120-5.

18. Zahran H.A, Abou-Talebb HK, Abdelgaleil SAM. Adulticidal, larvicidal and biochemical properties of essential oils against Culex pipiens L. J Asia-Pacific Entomology. 2017;20:133-9.

19. El-Sheikh TM. Field evaluation of repellency effect of some plant extracts against mosquitoes in Egypt. J Egypt Soc Parasitology. 2009;39(1):59-72.

20. Soliman MMM. Phytochemical and toxicological studies of Artemisia L. (Compositae) essential oil against some insect pests. Archives of Phytopathology and Plant Protection. 2007;40(2):128-38.

21. Onais E, Raad D, Bseiso Y. Analgesic and anti-inflammatory effects of an extract and flavonoids from Artemisia Herba-Alba and their mechanisms of action. Neurophysiology. 2014;46:238-46

22. Abdel-Shafy S, El-Khateeb RM, Soliman MM, Abdel-Aziz MM. The efficacy of some wild medicinal plant extracts on the survival and development of third instar larvae of Chrysomyia albiceps (Wied) (Diptera: Calliphoridae). Trop Anim Health Prod. 2009;41(8):1741-53.
23. Assar AA, El-Sobky MM. Biological and histopathological studies of some plant extracts on larvae of Culex pipiens (Diptera: Culicidae). J Egypt Soc Parasitology. 2003;33(1):189-200.

24. Namba, T, Hattori M, Takehana Y, Tsunezuka M, Tomimori T, Kizu H, Miyaichi, Y. A flavone from Artemisia capillaris. Phytochemistry. 1983;22(4):1057-8.

25. Yamamoto M, Ogawa K, Morita M, Fukuda K, Komatsu Y. The herbal medicine Inchin-ko-to inhibits liver cell apoptosis induced by transforming growth factor ß1. Hepatology. 1996;23(3):552-9.

26. Kiso $Y$, Ogasawara S, Hirota K, Watanabe N, Oshima $Y$, Konno C, Hikino $\mathrm{H}$. Antihepatotoxic principles of Artemisia capillaris buds. Planta Med. 1984;50(1):81-8.

27. Kiso Y, Sasaki, K, Oshima Y. Structure of arcapillin, an antihepatotoxic principle of Artemisia capillaris herbs. Heteroycles. 1982;19(9):1615-7.

28. Abu-Niaaj L, Katampe I. Isolation and characterization of flavones from Artemisia Monosperma. Pharmacog J. 2018;10(5):1018-23.

29. Umesh CV, Jamsheer AM, Alex PM. The role of flavonoids in drug discoveryReview on potential applications. RJLBPCS. 2018;4(1):70-7.

30. Wani, SA, lqbal H, Basir SF. Mechanism of flavonoids action in smooth muscle relaxation. World J of Pharmacy and Pharmaceutical Sciences. 2017;6(9):22784357.-

31. Jiang $H$, Xia $Q$, Wang $X$, Song J, Bruce IC. Luteolin induces vasorelaxation in rat thoracic aorta via calcium and potassium channels. Pharmazie. 2005;60(6):444 7.

32. Fusi F, Spiga O, Trezza A, Sgarali G, Saponara S. The surge of flavonoids as novel, fine regulators of cardiovascular $\mathrm{Ca}_{v}$ channels. Eur $\mathrm{J}$ of Pharmacolology 2017;796(5):158-74.

33. Fewtrell CM, Gomperts BD. Quercetin: A novel inhibitors of $\mathrm{Ca}^{2+}$ influx and exocytosis in rat peritoneal mast cells. Biochim Biophys Acta. 1977;269(1):5260.

34. Middleton E. jr. The flavonoids. Trends Pharmac Sci. 1984;5:335-8.

35. Miyazaki $Y$, Ichimura A, Sato S, Fujii T, Oishi S, Sakai $H$, Takeshima $H$. The natural flavonoid myricetin inhibits gastric $\mathrm{H}^{+}, \mathrm{K}^{+}-$ATPase. Eur J Pharmacology 2018;820: 217-21.

36. Ferrell JE, Chang Sing PDG, Loew G, King R, Mansour JM, Mansour TE. Structure/activity studies of flavonoids as inhibitors of cyclic AMP phosphodiesterase and relationship to quantum chemical indices. Molecular Pharmacology. 1979;16(2):556-68.

37. Islam MN, Jung, HA, Sohn HS, Kim HM, Choi JS. Potent $\alpha$-glucosidase and protein tyrosine phosphatase 1B inhibitors from Artemisia capillaris. Arch Pharmac Research. 2013;36(5):542-52.

38. Jung HA, Park JJ, Islam MN, Jin SE, Min BS, Lee JH, Sohn HS, Choi JS Inhibitory activity of coumarins from Artemisia capillaris against advanced glycation end product formation. Arch Pharmac Research. 2012;35(6):1021-35.

39. Somlyo A, Somlyo A. Ca ${ }^{2+}$ Sensitivity of smooth muscle and nonmuscle myosin II: Modulated by G proteins, kinases, and myosin phosphatase. Physiological Reviews. 2003:83(4):1325-58.

40. Harborne JB. The Flavonoids: Advances in Research since 1980. Springer Science \& Business Media 1988. Dordrecht.

41. Stefac M. Natural flavonoids as potential multifunctional agents in prevention of diabetic cataract. Interdisciplinary Toxicology. 2011;4(2):69-77.

42. Matsuda $H$, Wang T, Managi $H$, Yoshikawa $M$. Structural requirements of flavonoids for inhibition of protein glycation and radical scavenging activities. Bioorg. Med Chemistry. 2003;11:5317-23.

43. Flores-Flores A, Hidalgo-Figueroa S, Villalobos-Molina R, et al. Relaxant effect of structurally related flavonoids on isolated tracheal rat rings: a SAR study. Med Chem Res 2018;27:122-7.

44. Chau TT, Haley TJ. Flavonoid antagonism of the spasmogenic effect of angiotensin, bradykinin, and eledoisin on guinea-pig ileum. J Pharm Sci. $1969 ; 58: 621-3$ 


\section{GRAPHICAL ABSTRACT}

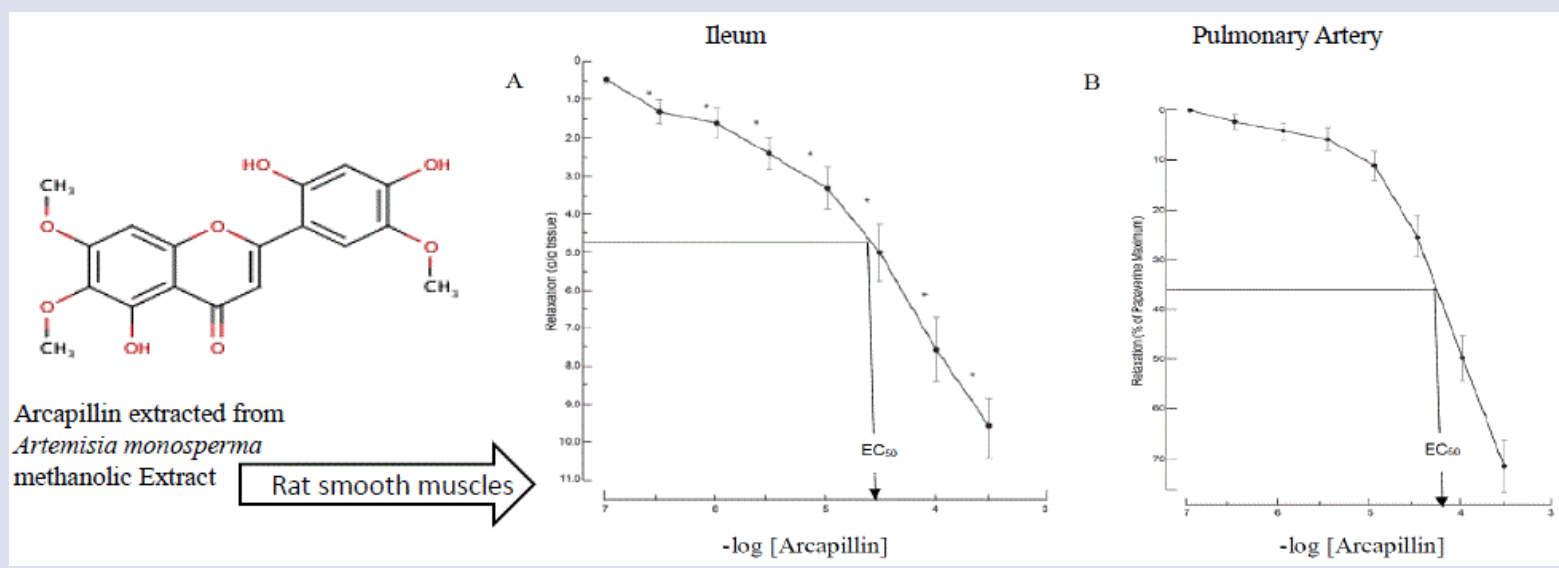

\section{SUMMARY}

- Arcapillin, 2',4',5-trihydroxy-5',6,7-trimethoxyflavone, was isolated for the first time from $A$. monosperma. It seems to contribute to the pharmaceutical importance of Artemisia species.

- The effect of arcapillin on smooth muscles was evaluated over eight cumulative concentrations of half log units in the range of $\left[10^{-7} \mathrm{M}-3 \times 10^{-4} \mathrm{M}\right]$.

- Arcapillin showed a concentration-dependent inhibition of ileal smooth muscle contraction with an $\mathrm{EC}_{50}$ of $2.8 \times 10^{-5} \mathrm{M}$.

- The highest concentration of arcapillin tested $\left(3 \times 10^{-4} \mathrm{M}\right)$ on ileum induced $\sim 65 \%$ relaxation compared to the maximum relaxation induced by papaverine. The induced inhibition was reversible within a minute upon washing off the flavone.

- Arcapillin caused a relaxation of the tone of contraction of the pulmonary artery muscle with an $\mathrm{EC}_{50}$ of $5.8 \times 10^{-5} \mathrm{M}$. The highest concentration tested $\left(3 \times 10^{-4} \mathrm{M}\right)$ induced $70.9 \%$ relaxation compared to the maximum relaxation caused by papaverine.

- Arcapillin in a concentration of $3 \times 10^{-5} \mathrm{M}$ slightly increased the contraction of the smooth muscle of the urinary bladder.

- Tracheal smooth muscles were not affected by all tested concentrations of arcapillin.

- The relaxation of ileum induced by arcapillin could be due to decreased availability of cytosolic calcium or due to an increased cAMP via inhibiting the phosphodiesterase enzyme. However, the contractile effect on the urinary bladder muscles could be due to inhibiting the $\alpha$-adrenergic receptors.

- The precise mechanism of action of arcapillin on smooth muscles should be investigated.

\section{ABOUT AUTHORS}

Dr. Lubna Abu-Niaaj is an Assistant Professor of Biology at Central State University, USA. Her molecular studies resulted in the deposition of Xenopus laevis SOCS1 cDNA sequence into the Database of the National Center for Biotechnology Information. Dr. Abu-Niaaj's publications are on muscle physiology, natural products and molecular genetics. Dr. Abu-Niaaj is a reviewer for multiple scientific journals and a member in several professional societies including the Society for Developmental Biology, American Society of Physiology and the American Society for Microbiology.

Dr. Ibrahim Katampe is an Associate Professor of Chemistry and currently the Assistant Director for Innovation \& Technology Incubation the College of Engineering, Science, Technology and Agriculture (CESTA), Central State University. Dr. Katampe is a research scientist with research and product development experiences in both academia and the private sectors. His research experiences include but not limited to advanced material synthesis, biological and chemical inhibition chemistries, biopolymers and natural product chemistry, waste water pollution remediation technologies. He is published in several Chemical and allied academic journals and is an inventor with about nine United States issued patents.

Dr. Shtaywy S. Abdalla is a Professor of Biology at the University of Jordan. He held several administrative positions as the provost, vice president for Science and Medical Faculties and others. He also served as the President of the Tafila Technical University. Dr. Abdalla has a Ph.D. in Physiology from the University of Wisconsin (USA). His research focuses on muscle physiology, endocrinology, hematology and inflammation on which he published more than 50 research papers in international journals. He authored and co-authored several books and under his supervision, more than 30 students earned their master's and doctorate degrees.

Cite this article: Abu-Niaaj LF, Katampe I, Abdalla SS. Evaluation of Antispasmodic Effect of Arcapillin on Rat Smooth Muscle. Pharmacog J. 2019;11(4):712-7. 